\title{
Production and Characterization of Mouse Diploid Parthenogenetic Blastocyst Developed in Phosphate-Free Medium
}

\author{
Vista Budiariati ${ }^{1}{ }^{2}$, Dwi Budiono ${ }^{2}$, Mokhamad Fahrudin ${ }^{2}$, Berry Juliandi ${ }^{3}$, Ratih Rinendyaputri ${ }^{4}$, Arief Boediono ${ }^{2 *}$ \\ ${ }^{1}$ Faculty of Veterinary Medicine, Universitas Gadjah Mada, Yogyakarta, Indonesia \\ ${ }^{2}$ Department of Anatomy, Physiology and Pharmacology, Faculty of Veterinary Medicine, IPB University, Bogor, Indonesia \\ ${ }^{3}$ Department of Biology, Faculty of Mathematics and Natural Sciences, IPB University, Bogor, Indonesia \\ ${ }^{4}$ Center for Research and Development of Biomedical and Basic Health Technology, National Institute of Health Research and \\ Development, Ministry of Health, Jakarta, Indonesia
}

ARTICLE INFO

\section{Article history:}

Received December 10, 2018

Received in revised form January 15, 2020

Accepted January 20, 2020

\section{KEYWORDS:}

parthenogenetic,

diploid,

blastocyst,

development,

characteristic,

phosphate-free

\begin{abstract}
Parthenogenesis is an artificial oocytes activation process without paternal contribution. Blastocyst, derived from parthenogenesis, is one of potential source for pluripotent stem cell propagation. Unfortunately, previous studies reported that parthenogenetic embryo did not achieve exhilarating blastocyst rate. One of the component that predicted inhibit parthenogenetic embryo development is phosphate. Therefore, we try to modify culture medium in order to overcome that problem. The aim of this research was to produce and analyze the characteristics of parthenogenetic blastocyst developed in phosphate-free medium. Mouse oocytes obtained from adult female DDY by superovulation. The activator was strontium chloride $10 \mathrm{mM}$ and diploidization with cytochalasin B $5 \mu \mathrm{g} / \mathrm{ml}$. Medium for activation and culture medium were modified rat 1 cell embryo medium (MR1ECM) which is phosphate free. The results showed that parthenotes that were cultured in phosphate free medium reached higher blastocyst rate compared to the other groups. The increase of phosphate in culture medium lead to impaired parthenogenetic embryos development. Further experiment was made to analyze the differences between fertilized and parthenogenetic embryo in this medium. The experiment showed that diploid parthenogenetic could achieve high blastocyst rate $(30.9 \pm 1.3 \%)$. The quality of diploid parthenogenetic blastocyst, based on cells number, viability, and ICM ratio, was lower than fertilized blastocyst.
\end{abstract}

\section{Introduction}

Embryonic stem cells (ESCs) comes from early embrional stage known as blastocyst. At this stage, embryo differentiates into two distinct lineages, trophectoderm and inner cell mass (Kidder 2014). The trophectoderm posseses epithelium characteristics and further develop and form extraembryonal tissue (Marikawa and Alarcon 2009). On the other hand, inner cell mass potentially capable to give rise to the three primary germ layer that later become all types of body cells. Therefore, stem cells derived from inner cell mass have pluripotency properties and can be classified as pluripotent stem cells.

Since the first invention of mouse ESCs in 1981 by Evans and Kaufman, then method for culturing

\footnotetext{
* Corresponding Author

E-mail Address: ab@apps.ipb.ac.id
}

human ESCs in 1998 by Thomson and Gearhardt, there are a lot of controversy related to this cells propagation (Robertson 2010). Most people against ESCs because they convice that embryos is a new life that has the same rights, moral, and legal status as an adult individual (Power and Rasko 2011). Hence, some countries prohibited ESCs research and restricted its funding.

An alternative source for pluripotent stem cells instead of fertilized embryo is parthenogenetic embryo (Baharvand 2009). Parthenogenesis is an artificial oocytes activation that lead to early embryonic development without fertilization by sperm (Paffoni et al. 2008). The discovery and the cellular mechanisms that occurs when sperms penetrate oocyte in the fertilization process become the basis knowledge of the development of parthenogenetic methods (Boediono et al. 1995). Unfortunately, parthenogenesis produces 
low number of good quality blastocyst, whereas blastocysts are the main material for stem cell propagation (Krivokharchenko et al. 2003).

One of the alleged element associated with blastocyst rate is phosphate. Haraguchi et al. (1996) reported that phosphate caused a negative effect on in vitro culture of $\mathrm{AKR} / \mathrm{N}$ mice fertilized embryos, removal of phosphate elements was significantly improved the blastocyst rate up to $42.6 \%$. The effects of phosphate also became an interesting finding in the study of Popova et al. (2011) that reported mouse fertilized embryos could well developed in modified medium rat 1 cell embryo medium (MR1ECM) which did not contain any phosphate. The effect of phosphate on in vitro culture of mouse parthenogenetic embryo has not been clear. Moreover, the characteristic of blastocyst derived from parthenogenesis in phosphate-free medium still not yet clear. Hence, the aim of this research was to produce and analyze the characteristics of diploid parthenogenetic blastocyst developed in phosphate free medium.

\section{Materials and Methods}

\subsection{Animals}

Adult female DDY mice were used in this study. Mice were housed under controlled temperature of $22-25^{\circ} \mathrm{C}$ and were kept on $12 \mathrm{~h}$ light conditions (06.00-18.00). Food and water supplied ad libitum. Experimental procedures of this research was approved by Animal Care and Ethics Committee of National Institute of Health Research and Development, Ministry of Health, Republic Indonesia (No:LB02.01/2/KE.150/2017).

\subsection{Superovulation, Oocytes and Fertilized Embryos Collection}

Female mice were induced to superovulation by intraperitoneal injection of 5 IU PMSG (Folligon ${ }^{\circledR}$, Intervet, Netherland) followed by 5 IU hCG (Chorulon ${ }^{\circledR}$, Intervet, Netherland) $48 \mathrm{~h}$ later. Mice were sacrificed 16 hours after hCG administration to collect cumulus oocytes complex. Hyaluronidase $0.1 \%(\mathrm{w} / \mathrm{v})$ was used to remove cumulus cells. Metaphase-II oocytes were used for parthenogenesis. To obtain fertilized embryos for experiment 2 , after hCG administration female mice were mated overnight with DDY males, then on the following morning the mice were examined for the presence of vaginal plugs. Handling medium was M2 medium (Sigma, St. Louis, USA).

\subsection{Parthenogenesis}

Oocytes were incubated for six hours exposure time in modified MR1ECM medium containing 10 $\mathrm{mM}$ strontium chloride $\left(\mathrm{SrCl}_{2}\right)$ (Sigma) and $5 \mu \mathrm{g} / \mathrm{ml}$ cytochalasin $\mathrm{B}$ at $37^{\circ} \mathrm{C}$ under $5 \% \mathrm{CO}_{2}$. The efficiency of activation was analyzed $6 \mathrm{~h}$ after treatment. Culture medium used in this study refers to the modified rat 1 cell embryo medium (MR1ECM) formulation reported by Popova et al. (2011).

\subsection{Experiment 1: Effect of Phosphate on the Parthenogenetic Embryos Development}

Six hours after activation, activated oocytes which had two pronuclei were cultured in phosphate-free medium (counted as $0 \mathrm{~h}$ ). Parthenotes were washed three times then divided into three groups with different phosphate concentration: no phosphate additives; 1 and $2 \mathrm{mM}$ phosphate. Embryos were cultured at $37^{\circ} \mathrm{C}$ and $5 \% \mathrm{CO}_{2}$ in drops of culture medium covered with mineral oil (Ovoil ${ }^{\mathrm{TM}}$, Vitrolife, Sweden). Embryos were examined at 48 and $96 \mathrm{~h}$. One way ANOVA continued with Duncan test were used for data analysis.

\subsection{Experiment 2: Comparison of Parthenogenetic and Fertilized Embryo Development in Phosphate- Free Medium}

Female mice with positive vaginal plugs after mating were sacrified then the zygotes were collected $18 \mathrm{~h}$ after hCG administration. Zygotes collected in PBS + $10 \% \mathrm{FBS}$, then were washed three times in MR1ECM. Fertilized embryos and diploid parthenogenetic were separately cultured in drops of MR1ECM, phosphatefree culture medium, at $37^{\circ} \mathrm{C}$ and $5 \% \mathrm{CO}_{2}$. Embryos were examined at 48 and $96 \mathrm{~h}$. Student $t$-tests were used to evaluate statistical differences of the parthenogenetic embryos development, cells number and viability of the blastocyst, and the data from ICM/blastocyst ratio measurement using Image-J software between the groups. A $\mathrm{p}<0.05$ was considered significant.

\subsubsection{Hoechst-Propidium lodide (HPI) Staining}

HPI staining was performed to determine the average number of cells and the rate of living or dead cells of the fertilized and parthenogenetic blastocyst. Blastocysts were incubated for $20 \mathrm{~min}$ at $37^{\circ} \mathrm{C}$ and $5 \% \mathrm{CO}_{2}$ in a $10 \mu \mathrm{g} / \mathrm{ml}$ Hoechst staining (Bisbenzimide $\mathrm{H}$ 33342, Sigma) and $10 \mu \mathrm{g} / \mathrm{ml}$ propidium iodide (Wako, Ozaka, Japan) then transferred to drop of PBS $+10 \%$ FBS and placed on an object glass gently covered with a cover glass. Stained blastocysts were 
observed under fluorescent microscope at 330-365 $\mathrm{nm}$ for Hoechst 33342 dye and 540-608 nm for propidium iodide (Eclipse E 6000, Nikon, Japan). The NIH Image-J application used for counting the total cells and live cells (blue) or dead cells (red).

\subsubsection{Image-J Measurement}

Twenty five digital images of the fertilized and parthenogenetic blastocysts were taken in sequence of 3 images on different focal planes, magnification 200x. The ratio between ICM diameter and blastocyst diameter were calculated using Image-J open source software after calibration with microscope micrometer calibration ruler. The ICM diameter was measured between the apex of the ICM and its base on the innerborder of the blastocyst (Almagor et al. 2016). The blastocyst diameter defined as the distance between the outside borders of the TE.

\section{Results}

Chemical activation was used in this study to induce parthenogenesis. Strontium chloride was the activator while cytochalasin B was selected for diploidization. Activation can be done and able to produce diploid embryo with 6 hours exposure time as shown in Figure 1.

The result of the first experiment of this study showed that mice parthenogenetic embryos could develop into blastocyst stage and reached higher levels of development rate in phosphate-free culture medium. Inhibitory effect occured along with the addition of phosphate. There were no blastocysts in concentration of $2 \mathrm{mM}$ phosphate in the culture medium as shown in Table 1.

Experiment 2 was conducted to compare the development and quality of parthenogenetic and fertilized blastocyst. The results showed that fertilized embryos developed better than parthenote. Blastocyst rate of fertilized embryo was $45.6 \%$, higher than parthenogenetic embryo that reached 30.9\% blastocyst rate. There were also a higher proportion of the parthenogenetic embryos which were arrested or grew slower at morula stage as shown in Table 2 .

Hoecht-PI staining was performed to count the total cells number and to calculate the viability of the blastocyst. Parthenogenetic blastocyst has lower cell
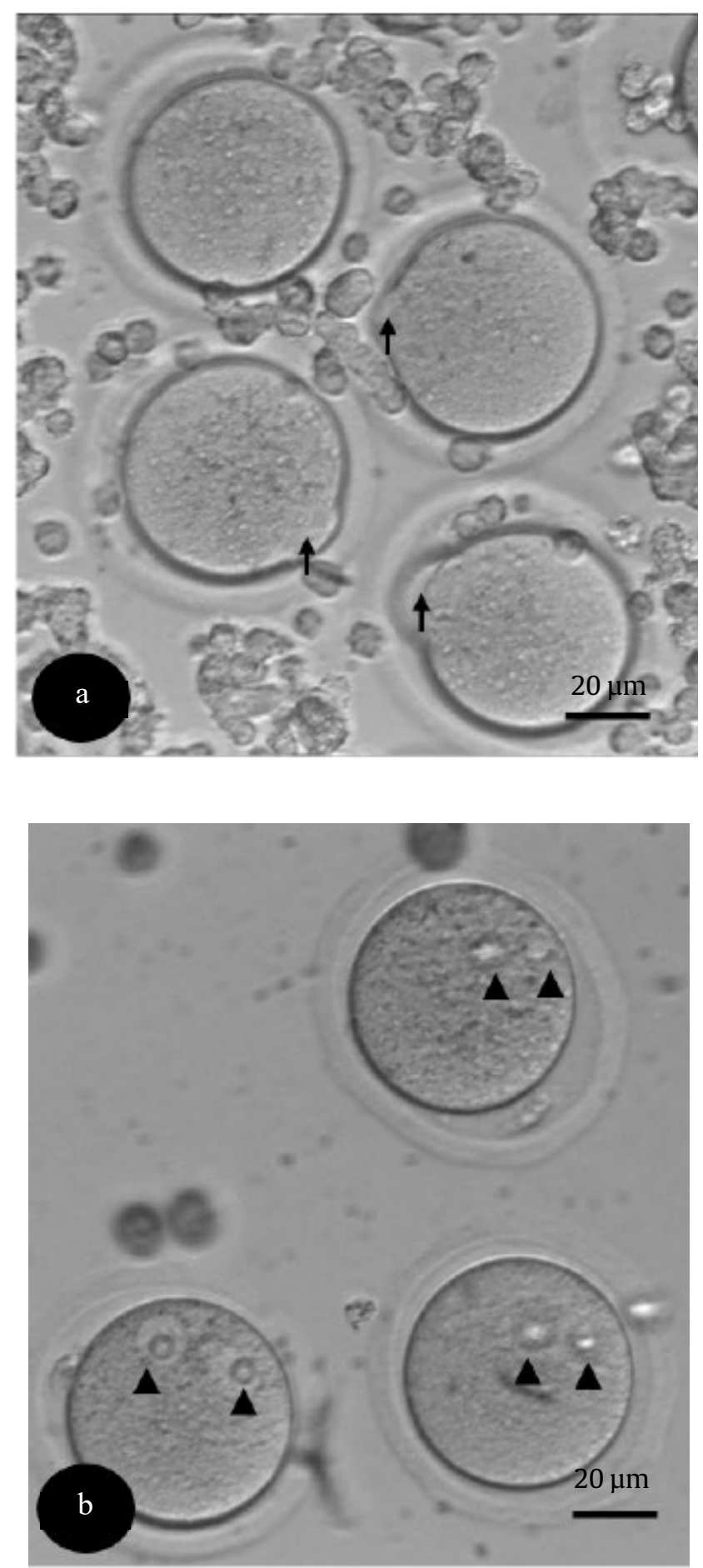

Figure 1. Diploidization of parthenogenetic mice oocytes (a) oocytes on metaphase II indicated by first polar body, prior to activation (black arrows: first polar body), (b) diploid parthenote with two pronuclei (black pointing triangle) after 6 hours exposure time in activation medium 
Table 1. Effect of phosphate on the parthenogenetic embryos development

\begin{tabular}{|c|c|c|c|c|c|}
\hline \multirow{2}{*}{ Phosphate concentration } & \multirow{2}{*}{$\begin{array}{c}\text { Total No. of } \\
\text { 2PN embryos }\end{array}$} & \multicolumn{4}{|c|}{ No. of embryos develop into (\%) } \\
\hline & & 2-cells & 4-cells & Morula & Blastocyst \\
\hline 0 & 30 & $26(86.6 \pm 1.3)$ & $18(59.8 \pm 3.8)^{\mathrm{a}}$ & $13(46.4 \pm 0.4)^{\mathrm{a}}$ & $9(29.9 \pm 1.9)^{a}$ \\
\hline $1 \mathrm{mM}$ & 34 & $29(85.6 \pm 2.9)$ & $20(53.1 \pm 2.9)^{b}$ & $6(18.1 \pm 3.6)^{b}$ & $2(9.4 \pm 2.4)^{b}$ \\
\hline $2 \mathrm{mM}$ & 37 & $32(86.8 \pm 1.8)$ & $16(43.4 \pm 0.9)^{c}$ & $3(8.5 \pm 2.3)^{c}$ & $0(0)^{c}$ \\
\hline
\end{tabular}

Three replicated trials were carried out. Percentages of embryos are based on number of total 2PN embryos and are expressed as mean+SEM. a, b. cValues with different letters within a column indicates significant differences, $\mathrm{p}<0.05$

Table 2. In vitro development of parthenogenetic embryo and fertilized embryo in modified rat medium (MR1ECM)

\begin{tabular}{lccccc}
\hline \multirow{2}{*}{ Group } & Total No. of & \multicolumn{4}{c}{ No. of embryos develop into (\%) } \\
\cline { 3 - 6 } & 2PN embryos & 2-cells & 4-cells & Morula & Blastocyst \\
\hline Parthenogenetic & 71 & $63(89.4 \pm 2.7)^{\mathrm{a}}$ & $42(59.6 \pm 1.8)^{\mathrm{a}}$ & $34(47.6 \pm 1.2)^{\mathrm{a}}$ & $22(30.9 \pm 1.3)^{\mathrm{a}}$ \\
Fertilized & 70 & $64(91.2 \pm 0.4)^{\mathrm{b}}$ & $50(72.1 \pm 1.1)^{\mathrm{b}}$ & $38(54.4 \pm 0.2)^{\mathrm{b}}$ & $32(45.6 \pm 0.2)^{\mathrm{b}}$ \\
\hline
\end{tabular}

Three replicated trials were carried out. Percentages of embryos are based on number of examined zygotes and are expressed as mean+SEM. a, bValues with different letters within a column indicates significant differences, $\mathrm{p}<0.05$

numbers (51.3 \pm 2.9$)$ compared to fertilized blastocyst (86.4 \pm 1.8$)$. Besides, the percentage of live cells that indicated the viability of the parthenogenetic blastocyst was also lower than the fertilized as shown in Table 3. Stained blastocyst observed under fluorosence microscope can be seen in Figure 2 .

Based on morphometrical analysis, diameter of fertilized blastocysts was $99.05 \pm 0.56$ and not significantly different with parthenogenetic blastocyst with average of diameter $99.91 \pm 0.48$. Nonetheless, the ratio of ICM-blastocyst of parthenogenetic blastocysts still lower than fertilized blastocyst as shown in Table 4 . The measurement of blastocyst in NIH Image-J demonstrated in Figure 3.

\section{Discussion}

Parthenogenesis is a reproductive strategy for some species of the classes of insects, pisces and amphibians. In those reproductive strategy, embryos will develop without fertilization by sperm so that paternal contributions are not involved in the parthenogenesis process (Paffoni et al. 2008). Parthenogenesis does not occurs in the natural reproduction of mammals but some research found that oocyte can be artificially activated by mimicking fertilization mechanism.

Activation of the oocytes in the fertilization process is due to an increase of intracellular calcium. During fertilization, sperm penetrates the oocyte and induces intracellular calcium oscillation to activate the oocytes. The sperm factor phospholipase $\zeta$ (PLC $\zeta$ ) facilitates the hydrolysis of phosphatidylinositol 4.5-bisphosphate (PIP2) to diacylglycerol (DAG) and inositol triphosphate (IP3). This event leads to calcium influx from reticulum endoplasmic as an intracellular calcium deposits (Saunders et al. 2002; Swann et al. 2004; Heytens et al. 2009). There will be inactivation of maturation promotion factor (MPF) and mitogen activated protein kinase (MAPk) following calcium influx, which promotes meiosis, DNA synthesis and pronucleus formation (Paffoni et al. 2008).

Artificial activation by chemical compounds can be done using some chemicals such as $\mathrm{Ca}^{2+}$ ionophores, ethanol 7\%, strontium chloride, phorbol ester, ionomycin and thimerosal. Strontium chloride induces a recurrent increase by unbound the calcium of the oocyte and induce multiple oscillations from endoplasmic reticulum. Strontium is known as a very effective activator agent in mice oocytes (O'Neill et al. 1991) and could activated the mice oocytes after nuclear transfer (Wakayama et al. 1998). In order to produce diploid embryos from parthenogenesis mechanism, cytochalasin B is needed to prevent the second polar body extrusion.

Popova et al. (2011) published that development of early preimplantation embryos is altered by different in vitro culture conditions including medium composition. Experiment 1 showed that there was an inhibitory effect caused by phosphate addition in the culture medium started at 4 cell stage. 
Table 3. Comparison of total cells number, percentage of live and dead cells from parthenogenetic blastocyst and fertilized blastocyst

\begin{tabular}{lccr}
\hline Blastocyst & Cell numbers & Live cells (\%) & Dead cells (\%) \\
\hline Parthenogenetic & $51.3 \pm 2.9^{\mathrm{a}}$ & $40.3 \pm 2.9(78.7)^{\mathrm{a}}$ & $10.9 \pm 2.1(21.3)^{\mathrm{a}}$ \\
Fertilized & $86.4 \pm 1.8^{\mathrm{b}}$ & $78.8 \pm 1.5(91.2)^{\mathrm{b}}$ & $7.6 \pm 0.82 .1(8.8)^{\mathrm{b}}$ \\
\hline
\end{tabular}

Cell numbers are expressed as mean+SEM. ${ }^{\mathrm{a}, \mathrm{b}}$ Values with different letters within a column indicates significant differences, $\mathrm{p}<0.05$

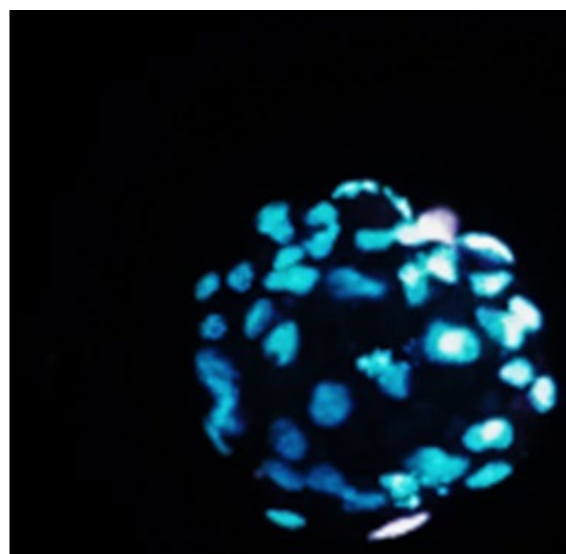

$\mathrm{a}$

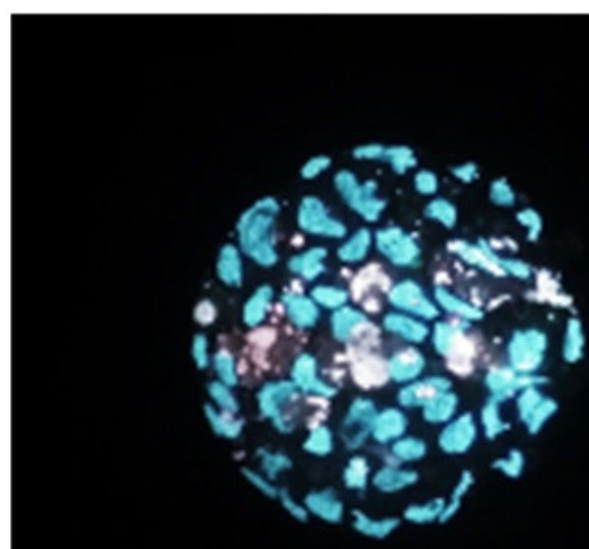

b

$20 \mu \mathrm{m}$
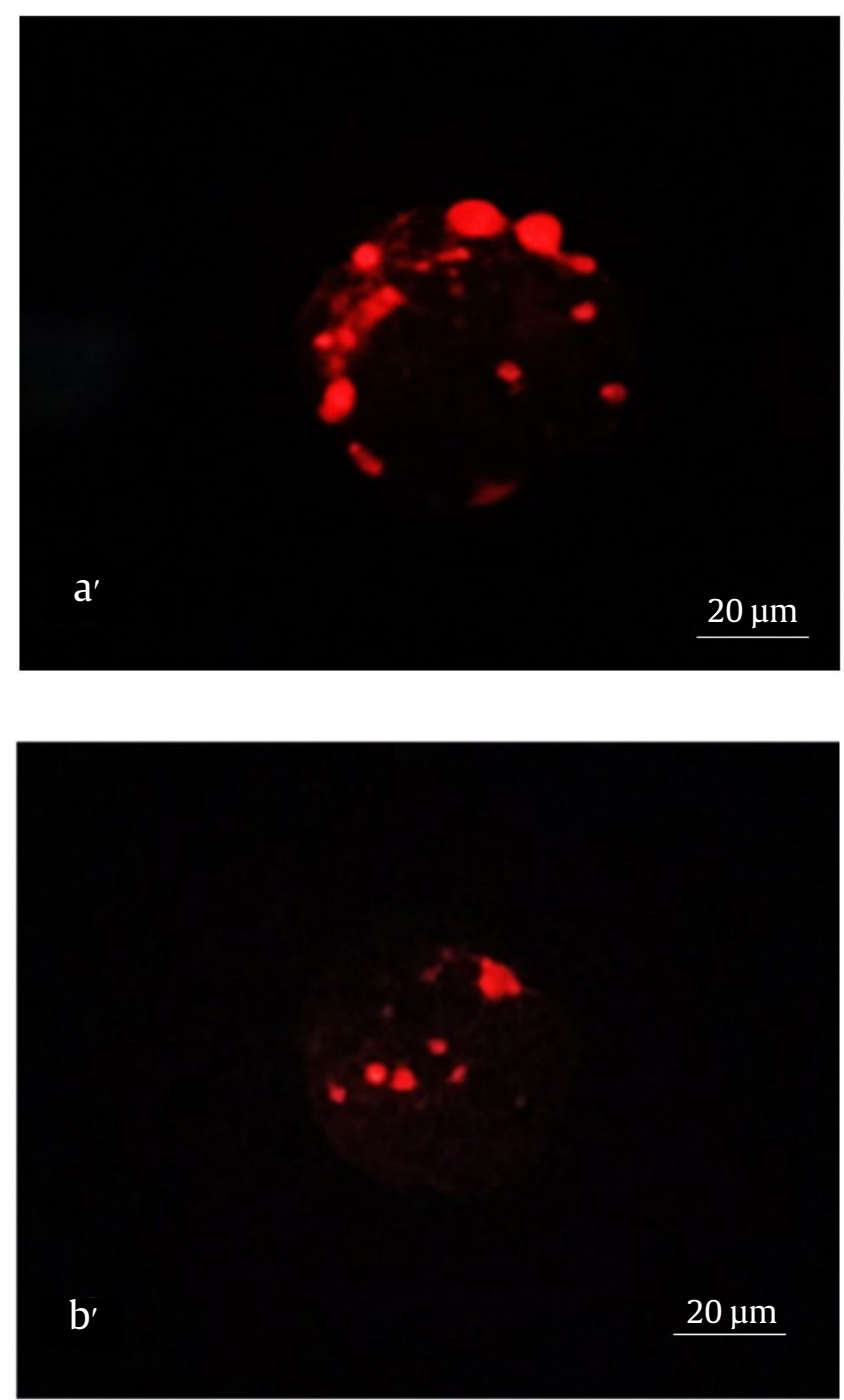

Figure 2. Hoechst-propidium iodide staining (a) live cells of parthenogenetic blastocyst, ( $\left.a^{\prime}\right)$ dead cells of parthenogenetic blastocyst, (b) live cells of fertlized blastocyst, ( $\left.b^{\prime}\right)$ dead cells of fertilized blastocyst

Table 4. Morphometrical characterictic of fertilized and parthenogenetic blastocyst developed in phosphate-free medium

\begin{tabular}{lcccc}
\hline & $\mathrm{n}$ & $\emptyset$ Blastocyst $(\mu \mathrm{m})$ & $\emptyset \mathrm{ICM}(\mu \mathrm{m})$ & Ratio ICM/Blastocyst \\
\hline Parthenogenetic blastocyst & 25 & $99.91 \pm 0.48$ & $20.41 \pm 0.41^{\mathrm{a}}$ & $0.21^{\mathrm{a}}$ \\
Fertilized blastocyst & 25 & $99.05 \pm 0.56$ & $31.94 \pm 0.58^{\mathrm{b}}$ & $0.32^{\mathrm{b}}$ \\
\hline
\end{tabular}

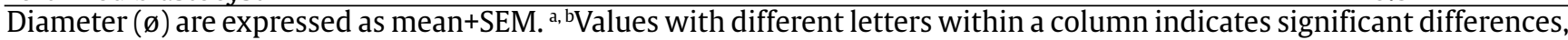
$\mathrm{p}<0.05$ 

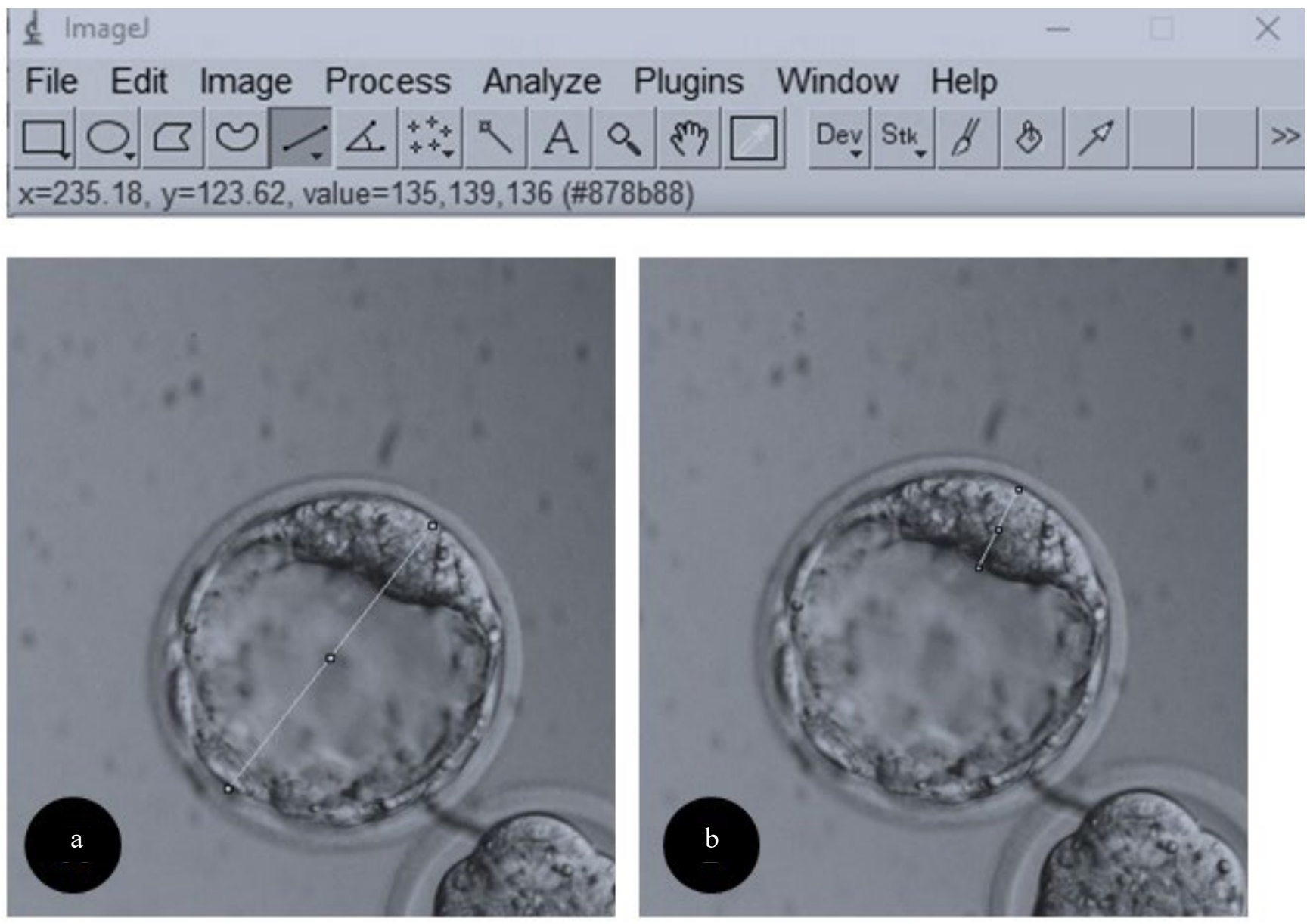

\& Results
\begin{tabular}{l|l|l|l|l|l|l|l|} 
File Edit & Font Results \\
\hline & Area & Mean & StdDev & Min & Max & Angle & Length \\
\hline 1 & 16.778 & 135.087 & 20.023 & 72.061 & 175.619 & 56.070 & 99.931 \\
2 & 4.461 & 124.173 & 33.936 & 75.852 & 200.938 & 62.949 & 26.519
\end{tabular}

Figure 3. Examples of simple method blastocyst morphometrical measurement in one focal planes using NIH Image-J (a) blastocyst diameter, (b) ICM diameter

Haraguchi et al. (1996) reported that there was significant decrease in the development of $\mathrm{AKR} / \mathrm{N}$ mouse to 4-cell stage embryo with 0.001 $\mathrm{mM}$ phosphate and embryos did not reach morula stage in concentration of $1.0 \mathrm{mM}$ phosphate. These phenomenon of sensitivity to phosphate were also reported found in rat embryos (Matsumoto and Sugawara 1998) and hamster embryo culture (Barnett and Bavister 1996).

The inhibitory effect of the presence of phosphate could be related to maturation promoting factor
(MPF) activity. It has been reported that MPF plays an important role and control cell division activity (Yu et al. 2008). This kinase promotes the cell to enter the $\mathrm{M}$ phase. The presence of phosphate in culture medium may prevents second cleavage by inhibit the activation of MPF in the second cell cycle. The mechanism of MPF activity entails cyclin B synthesis and dephosphorylation of cdc2.

Experiment 2 was conducted to compare fertilized and parthenotes development in phosphate free medium. The results showed that fertilized embryo 
developed better as indicated by higher development rate from cleavage stage and morula to blastocyst stage compared to parthenogenetic blastocyst. We predicted that it has correlation with different mechanism on embryonic genome activation.

Naturally, there will be a control transition from maternal genome to embryonic genome which is the first critical events in the life of the new organism (Latham and Schultz 2001). Previous study explained that genome activation in the mouse started at the 2 -cell stage, with a minor activation event at the early 2-cell stage and a major activation event at the late 2-cell stage (Flach et al. 1982). The transitions of genomic control are needed to provide transcription factor that are required for DNA replication and cell cleavage (Jukam et al. 2017). Unlike fertilized embryo, parthenotes lack paternal factor so that there will be no transitions of genome control from maternal to zygotic genome activation. Because of that reason, parthenotes will not develop as good as fertilized embryos.

The blastocyst rate in modified phosphate free medium showed better results compared to previous studies. Hine et al. (2009) reported that the development rate of parthenogenetic embryos to blastocyst stage in KSOM medium was $13.30 \%$ while in CZB medium 6.11\%. Murti et al. (2014) published 8.6\% parthenogenetic development rate in CZB medium with $5.55 \mathrm{mM}$ D-glucose. We analyzed and found that there was different phosphate concentration between KSOM and CZB medium. KSOM medium has a lower phosphate content compared to CZB medium. The KSOM medium contains $0.35 \mathrm{mM}$ phosphate while the phosphate concentration in CZB medium is $1.18 \mathrm{mM}$ (Nagy et al. 2003). This is strengthen the indication of the negative effects of phosphate on the development of parthenogenetic embryos.

One of the potential prospect of parthenogenetic blastocyst is to be used as an alternative sources for pluripotent stem cells (Daughtry and Mitalipov 2014). To reach this goal, we have to ensure that we did not only elevate the development rate of parthenogenetic blastocyst but also improve the quality of the blastocyst. Because of this reason, we counted mean cells number and the viability of the blastocyst by hoechst-pi staining. We found that parthenogenetic blastocyst had lower cell number compared to fertilized blastocyst. This is because the number of dead inner cell mass and trophoblast cells was significantly more in parthenogenetic embryos than in fertilized one (Niimura et al. 2002). Unfortunately, stained blastocyst can not be used to derivate parthenogenetic embryonic stem cells. Therefore, this study elaborate a noninvasive method to estimate the proportion of inner cell mass of the parthenogenetic blastocyst using digital images measurement approach. Almagor et al. (2016) reported that inner cell mass diameter and blastocyst diameter is correlated with successful pregnancy outcomes of single blastocyst transfers. The ICMto-blastocyst diameter ratio is a one of the predictor of implantation and live birth in single-blastocyst transfers. In short, it can be used as one of blastocyst quality parameter.

The measurement of blastocyst morphometry showed that there was no difference between the diameter of parthenogenetic and fertilized blastocyst. There are some factors that affected blastocyst diameter including blastocoel volume and diameter of zona pelucida. The ratio of parthenogenetic blastocyst ICM was lower than a fertilized blastocyst. This is in line with the result of mean cell numbers calculation of parthenogenetic blastocyst cells that are also lower than the fertilized blastocyst.

In conclusion, mice parthenogenetic embryos develop better in phosphate-free medium. The quality of parthenogenetic blastocyst, based on cell number, viability, and ICM ratio parameters, was lower than for fertilized blastocyst. The characteristics of parthenogenetic diploid blastocyst in the phosphate-free medium are blastocyst rate up to $30 \%$, have a mean cell number $51.3 \pm 2.9$, viability of $78.7 \%$, diameter of $99.91 \pm 0.48 \mu \mathrm{m}$ and ICM/blastocyst ratio 0.21 .

\section{Conflicts of Interest}

The authors declare that there is no conflict of interest on this research.

\section{Acknowledgements}

This study was funded and supported by Directorate General of Higher Education (DGHE) Indonesia through the PMDSU Study Grant Program 136/SP2H/LT/DRPM/IV/2017. The authors also would like to thank the National Institute of Health Research and Development, Ministry of Health, Indonesia for the supports and laboratory facilities. 


\section{References}

Almagor M et al. 2016. Ratio between inner cell mass diameter and blastocyst diameter is correlated with successful pregnancy outcomes of single blastocyst transfers. Fertil Steril 106:1386-1391.

Baharvand 2009. Trends in Stem Cell Biology and Technology. 1st ed. New York: Springer Publishing.

Barnett D, Bavister. 1996. Inhibitory effect of glucose and phosphate on the second cleavage division of hamster embryos: is it linked to metabolism? Hum Reprod $11: 177-183$

Boediono A et al. 1995. Development in vitro and in vivo of aggregated parthenogenetic bovine embryos. Reprod Fertil Dev 7:1073-1079.

Daughtry B, Mitalipov S. 2014. Concise review: parthenote stem cells for regenerative medicine: genetic, epigenetic, and developmental features. Stem Cells Transl Med 3:290-298.

Flach G et al. 1982. The transition from maternal to embryonic control in the 2-cell mouse embryo. EMBO J1:681-686.

Haraguchi S et al. 1996. Effects of phosphate on in vitro 2-cell block of AKR/N mouse embryos based on changes in cdc2 kinase activity and phosphorylation states. Biol Reprod 55:598-603.

Heytens E et al. 2009. Reduced amounts and abnormal forms of phospholipase Czeta (PLCzeta) in spermatozoa from infertile men. Hum Reprod 24:2417-2428.

Hine TM. 2009. Pengembangan Metode Kultur Embryonic Stem Cells dari Embrio Hasil Fertilisasi dan Produksinya dari Embrio Partenogenetik Mencit [Disertasi]. Bogor, Indonesia: Institut Pertanian Bogor.

Jukam D et al. 2017. Zygotic genome activation in vertebrates. Dev Cell 42:316-332.

Kidder B. 2014. Stem Cell Transcriptional Networks Methods and Protocols. New York: Springer.

Krivokharchenko Aet al.2003.Development of parthenogenetic rat embryos. Biol Reprod 68:829-836.

Latham K, Schultz R. 2001. Embryonic genome activation. Front Biosci 1:748-759.

Marikawa Y,Alarcon VB. 2009. Establishment of trophectoderm and inner cell mass lineages in the mouse embryo. Mol Reprod Dev 76:1019-1032.
Matsumoto, Sugawara S. 1998. Effect of phosphate on the second cleavage division of the rat embryo. Hum Reprod 13:398-402.

Murti $\mathrm{H}$ et al. 2014. Perkembangan praimplantasi embrio mencit dengan materi genetik yang berasal dari paternal, maternal, dan inti sel somatik.J Vet 15:1-10.

Nagy A et al. 2003. Manipulating Mouse Embryo a Laboratory Manual. New York: Cold Spring Harbor Laboratory Press.

Niimura S et al. 2002. The number of cells and the rate of cell division in parthenogenetic and fertilized mouse embryos during the course of blastocyst formation.J Mamm Ova Res 19:66-70.

O'Neill G et al. 1991. Developmental potential and chromosome constitution of strontium-induced mouse parthenogenones. Mol Reprod Dev 30:214-219.

Paffoni A et al. 2008. Parthenogenetic activation: biology and applications in the ART laboratory. Placenta:121-125.

Popova E et al. 2011. Effect of culture conditions on viability of mouse and rat embryos developed in vitro. Genes (Basel) 2:332-344.

Power C, Rasko J. 2011. Will cell reprogramming resolve the embryonic stem cell controversy? a narrative review. Ann Intern Med 155:114-121.

Robertson JA. 2010. Embryo stem cell research: ten years of controversy. J Law Med Ethics 38:191-203.

Saunders M et al. 2002. PLCzeta: a sperm-specific trigger of $\mathrm{Ca}^{2+}$ oscillations in eggs and embryo development. Development 129:3533-3544.

Swann Ket al. 2004. The cytosolic sperm factor that triggers $\mathrm{Ca}^{2+}$ oscillations and egg activation in mammals is a novel phospholipase C: PLCzeta. Reproduction 127:431439.

Wakayama T et al. 1998. Full-term development of mice from enucleated oocytes injected with cumulus cell nuclei. Nature 23:394-374.

Yu A et al. 2008. Regulation of cAMP on the first mitotic cell cycle of mouse embryos. Mol Reprod Dev 75:489-495. 